\title{
Demand Driven Common Bean Variety Development and Promotion for Enhanced Productivity and Production ${ }^{\dagger}$
}

\author{
Berhanu Amsalu Fenta 1,* , Kassay Negash 1, Kidane Tumssa 1, Tigist Shiferaw 1, \\ Dagmawit Tsegaye ${ }^{1}$, Rubyogo Jean Claude ${ }^{2}$ and Clare Mugisha Mukankusi ${ }^{3}$ \\ 1 Ethiopian Institute of Agricultural Research, Melkassa Research Centre, P.O. Box 436, Ethiopia; \\ kassayend@gmail.com (K.N.); ktumsa@gmail.com (K.T.); tshiferaw2006@gmail.com (T.S.); \\ damy.we@gmail.com (D.T.) \\ 2 Pan Africa bean Research Alliance (PABRA), CIAT Africa, C/O Selian Agricultural Research Institute, \\ P.O. Box 2704 Arusha, Tanzania; j.c.rubyogo@cgiar.org \\ 3 Center for International Tropical Agriculture (CIAT), P.O. Box 6247 Kampala, Uganda; \\ c.mukankusi@cgiar.org \\ * Correspondence: berhanufenta@gmail.com \\ † Presented at the Third International Tropical Agriculture Conference (TROPAG 2019), Brisbane, Australia, \\ 11-13 November 2019.
}

Published: 2 April 2020

\begin{abstract}
Common bean research program of Ethiopia aimed at development of demanded variety for enhanced adoption, improve food and nutrition security as well as to boost income of smallholder farmers thereby enhancing foreign earnings of the country. To achieve these aim, the breeding program use different strategies. These incudes, importing demanded variety and fasttrack testing release, introducing bean germplasm and release stable variety and participatory variety selection for incorporating growers traits on variety selection. Accordingly, bean improvement program selected six major bean products that includes, small/large white beans, speckled bean, small/large reds and mottled beans. During variety selection stakeholders' choice and trait of preference has been incorporated during interactive consultative forums of the value chain actor at bean innovation multi-stakeholder platform. Apart from bean variety development, integrated crop management technologies has been developed to implement good agricultural practice. To facilitate common variety adoption, bean seed system have been enhanced through integration of early generation seed production with formal and informal seed production of public and private seed producers. These efforts has enhanced transformed productivity from 0.7 to 1.5 t/ha and area expanded from 150,000 ha to 520,121 ha and total production up to 568,243 t. Due to this fact bean export has been increased up to 100-150 million USD per annum. Generally, the demand led breeding and value chain approach, synergetic and innovative technology generation and promotion has transformed bean productivity, area produced and market; consecutively livelihood of growers and income of the country has been enhanced.
\end{abstract}

Keywords: common bean; demand led breeding; seed system; multi-stakeholders; platform

Author Contributions: B.A.F., K.N., K.T., T.S. and D.T.: have been contributed in demand led variety development and promotion. R.J.C. and C.M.M., have been contributed in supporting germplasm for breeding program, supporting the program in facilitating financial and technical support in bean technology generation and promotion. 
Funding: This research received Ethiopian government funding as well as external fund support by TROPICAL LELGUME III (TL III) project, grant number C-075-18 and “The TL III was funded by CIAT".

Acknowledgments: We are grateful with the technical, financial and material support, done by Pan Africa Bean Research Alliance (PABRA), Center for International Tropical Agriculture (CIAT)-Africa.

Conflicts of Interest: The authors declare no conflict of interest.

(C) 2020 by the authors. Licensee MDPI, Basel, Switzerland. This article is an open access article distributed under the terms and conditions of the Creative Commons Attribution (CC BY) license (http://creativecommons.org/licenses/by/4.0/). 